\title{
Penerapan Model Numbered Head Together Berbantu Gambar Ilustrasi Untuk Meningkatan Hasil Belajar Pendidikan Kewarganegaraan Siswa SD
}

\section{Runita Firdayanti, Nur Fajrie, dan Sumarwiyah}

Universitas Muria Kudus, Indonesia

Email: runitafirdayanti845@gmail.com

\section{Info Artikel}

Sejarah Artikel:

Diserahkan 19 Agustus 2021

Direvisi 18 Oktober 2021

Disetujui 25 Oktober 2021

Keywords:

Number Head Together,

Illustration picture,

learning outcomes

\section{Abstract}

This study aims to describe the improvement of fourth grade students' learning outcomes at SD 2 Bae on Citizenship Education (Civics) subjects through the application of the Numbered Heads Together learning model with illustrations.

This research is a classroom action research that uses Kemmis and Mc Tanggart's research design which is carried out in 2 cycles. Each cycle consists of 4 stages, namely planning, implementation, observation and reflection. The research subjects consisted of 15 students in grade IV SD 2 Bae. The independent variable in this study is the Numbered Head Together learning model assisted by illustrations, while the dependent variable is the learning outcomes of fourth grade students of SD 2 Bae. Data collection techniques in this study used observation, interviews, tests, and documentation. The data analysis technique used is quantitative data analysis which is strengthened by qualitative data.

The results of classroom action research showed an increase in student learning outcomes in the cognitive domain from $71 \%$ in the first cycle to $82.33 \%$ in the second cycle. In the affective domain, it increased by a percentage of $72.67 \%$ in the first cycle to $81.83 \%$ in the second cycle. The psychomotor domain experienced an increase in the percentage from $74.33 \%$ in the first cycle to $82.5 \%$ in the second cycle. The application of the Numbered Heads Together learning model with the help of illustrations can improve Civics learning outcomes on the subject of globalization in the cognitive, affective, and psychomotor domains.

\begin{abstract}
Abstrak
Penelitian ini bertujuan untuk mendiskripsikan peningkatan hasil belajar siswa kelas IV SD 2 Bae pada mata pelajaran Pendidikan Kewarganegaraan (PKn) melalui penerapan model pembelajaran Numbered Heads Together berbatu gambar ilustrasi.

Penelitian ini merupakan penelitian tindakan kelas yang menggunakan desain penilitian Kemmis dan Mc Tanggart yang dilakukan dalam 2 siklus. Setiap siklus terdiri dari 4 tahap yakni perencanaan, pelaksanaan, pengamatan dan refleksi. Subjek penelitian terdiri dari siswa kelas IV SD 2 Bae sebanyak 15 siswa. Variabel bebas dalam penelitian ini adalah model pembelajaran Numbered Head Together berbantu Gambar ilustrasi, sedangkan variabel terikatnya adalah hasil belajar siswa kelas IV SD 2 Bae. Teknik pengumpulan data dalam penelitian ini menggunakan observasi, wawancara, tes, dan dokumentasi. Teknik Analisis data yang digunakan merupakan analisis data kuantitatif yang diperkuat dengan data kulalitatif.

Hasil penelitian tindakan kelas menunjukkan adanya peingkatan pada hasil belajar siswa ranah kognitif dari siklus I $71 \%$ menjadi $82,33 \%$ pada siklus II. Pada ranah afektif meningkat dengan presentase $72,67 \%$ pada siklusI menjadi $81,83 \%$ pada siklus II. Ranah psikomotorik mengalami peningkatan presentase dari $74,33 \%$ pada siklus I menjadi $82,5 \%$ pada siklus II. Penerapan model pembelajaran Numbered Heads Together berbantu gambar ilustrasi dapat meningkatkan hasil belajar PKn materi globalisasi ranah kognitif, afektif, dan psikomotorik
\end{abstract}




\section{PENDAHULUAN}

Pendidikan Kewarganegaraan (PKn) khususnya untuk siswa sekolah dasar memiliki arti yang penting. Pendidikan Kewarganegaraan sebagai jembatan dalam pembentukan pribadi warga negara yang mampunmemahami dan melaksanakan hak-hak dan kewajiban sebagai warga negara Indonesia yang cerdas, terampil dan berkarakter sesuai dengan yang diamanatkan dalam Pancasila dan Undang-Undang Dasar 1945. Undang-Undang Nomor 2 Tahun 1989 tentang Sistem Pendidikan Nasional menjelaskan bahwa Pendidikan Kewarganegaraan merupakan sebuah usaha untuk membekali siswa dengan pengetahuan dan kemampuan dasar tentang hubungan antara warga negara dan negara serta Pendidikan Pendahuluan Bela Negara (PPBN) agar menjadi warga negara yang dapat diandalkan oleh bangsa dan Negara Kesatuan Republik Indonesia".

Menurut Magdalena, dkk (2020) hakikat Pendidikan Kewarnegaraan di Sekolah Dasar (SD) merupakan program pendidikan berdasarkan nilai-nilai pancasila dengan tujuan untuk mengembangkan dan melestarikan nilai luhur dan moral yang berakar pada budaya bangsa yang menjadi jati diri siswa yang diwujudkan dalam bentuk perilaku dalam kehidupan sehari hari. PKn merupakan mata pelajaran yang mempelajari tentang penanaman karakter, demokrasi dan tata negara, yang bertujuan untuk membentuk warga negara yang memilki tanggung jawab, rasa cinta dan bela negara kepada bangsa Indonesia.

Peran guru sangat diperlukan untuk membekali dan mengembangkan nilai sikap dan moral pada diri siswa di sekolah dasar. Untuk mewujudkan semua itu perlu adanya perencanaan yang matang oleh guru dalam melaksanakan proses pembelajaran sehingga proses pembelajaran dapat berlangsung secara efektif dan efisien. Pembelajaran yang efektif dan efisien adalah pembelajaran yang mampu mengembangkan potensi siswa, adanya interaksi antar guru dengan siswa yang terarah dengan menerapkan sebuah model pembelajaran inovatif dan konstruktif. Penggunaan media dalam pembelajaran juga dibutuhkan untuk membantu menyampaikan informasi atau materi dan membuat pembelajaran menjadi lebih berarti (Ardianti dkk, 2021). Untuk mencapai tujuan pendidikan harus berorientasi pada pengembangan seluruh aspek potensi siswa, di antaranya aspek kognitif, afektif dan berimplikasi pada aspek psikomotorik.

Berdasarkan hasil observasi yang dilakukan tanggal 9 Oktober 2017 kepada guru dan siswa kelas IV SD 2 Bae menunjukkan bahwa hasil
Ulangan Harian siswa kelas IV SD 2 Bae terdapat 10 siswa dari 15 siswa yang tidak mencapaikan Kriteria Ketuntasan Minimal (KKM). KKM PKn di SD 2 Bae adalah 70. Dari data tersebut diketahui bahwa sejumlah $66,7 \%$ siswa tidak tuntas KKM dan hanya sebesar 33,3\% siswa tuntas KKM. Hal tersebut sebagai salah satu indikator rendahnya hasil belajar siswa pada mata pelajaran $\mathrm{PKn}$.

Beberapa faktor yang menyebabkan rendahnya hasil belajar siswa kelas IV SD 2 Bae yaitu berdasarkan wawancara guru tidak menerapkan model dan menggunakan media pembelajaran yang sesuai dengan materi dan karakteristik siswa. Guru seringkali hanya menggunakan metode ceramah dalam menyampaikan materi yang bersifat hafalan. Selain itu, tidak semua siswa aktif dan ikut berpartisipasi dalam kegiatan pembelajaran mereka cenderung tidak mau mendengarkan penjelasan guru justru siswa bermain sendiri dan berbicara dengan temannya. Hasil wawancara yang dilakukan dengan siswa diketahui bahwa keaktifan siswa dalam pembelajaran tidak merata, hanya siswa yang pintar mendominasi pembelajaran sehingga membuat siswa kurang bertanggung jawab terhadap tugas ataupun pembelajaran karena mereka merasa tidak diperhatikan oleh gurunya. Siswa merasa cepat bosan dalam pembelajaran karena mereka hanya mendengarkan ceramah tanpa ada aktivitas lainnya. Keterlibatan siswa dalam pembelajaran masih kurang, sehingga siswa jenuh dan akhirnya tidak memperhatikan kegiatan pembelajaran.

Perlu adanya inovasi pembelajaran sebagai solusi untuk peningkatan kualitas pembelajaran di kelas IV SD 2 Bae Kudus. Guru perlu merencanakan pembelajaran yang dapat meningkatkan keterlibatan siswa dalam pembelajaran melalui penerapan model pembelajaran maupun dengan bantuan penggunaan media pembelajaran. Numbered Head Together (NHT) sebagai salah satu model pembelajaran kooperatif yang dapat membantu meningkatkan aktivitas siswa. Model NHT sebagai model pembelajaran dengan membagi siswa menjadi beberapa kelompok heterogen yang memungkinkan siswa untuk bekerjasama dan bertukar pikiran untuk menyelesaikan suatu masalah yang diberikan oleh guru (Arsini dkk, 2015). Selaras dengan pendapat Sumani (2016) bahwa penggunaan model NHT dapat meningkatkan aktivitas siswa yang berdampak pada kemampuan dan pemahaman siswa terhadap materi pelajaran. Dalam model pembelajaran NHT setiap siswa dituntut bertanggung jawab sehingga dalam bekerja 
kelompok tidak ada yang mendominasi dan semua siswa berani mengungkapkan pendapatnya (Sofyan \& Agustang, 2018). Model NHT dapat memberikan motivasi bagi siswa untuk tetap semangat dalam mengikuti pembelajaran, siswa tidak hanya berdiam diri saja tetapi ikut aktif selama mengikuti pembelajaran.

Model NHT dalam penerapannya akan lebih optimal jika disertai dengan penggunaan media pembelajaran. Gambar ilustrasi sebagai salah satu media pembelajaran yang mudah dipersiapkan oleh guru. Gambar ilustrasi mendukung dalam penerapan model NHT sebagai media pembelajaran yang bersifat konkrit, lebih realistis, mengatasi batasan ruang dan waktu serta mengatasi keterbatasan pengalaman kita (Nikmah, 2018). Gambar ilustrasi juga berfungsi untuk memberikan daya tarik atau hiasan dari tampilan buku, majalah dan sejenisnya yang membuat siswa lebih tertari sehinngga memunculkan motivasi untuk mengikuti pembelajaran (Annisa dkk, 2021). Penerapan model NHT berbantu gambar ilustrasi bertujuan supaya siswa lebih aktif, kreatif dan bermakna dalam mengikuti pembelajaran.

Tujuan penelitian ini adalah untuk mendiskripsikan peningkatan hasil belajar Pendidikan Kewarganegaraan siswa Kelas IV SD 2 Bae setelah diterapkannya model pembelajaran Numbered Head Together berbantu gambar ilustrasi.

\section{METODE PENELITIAN}

Penelitian ini merupakan Penelitian Tindakan Kelas (PTK) dengan model Kemmis dan Mc. Taggart (dalam Sugiyono, 2014). Langkah PTK yang digunakan meliputi empat langkah yaitu 1) Perencanaan; 2) pelaksanaan; 3) pengamatan; dan 4) Refleksi.

Subjek dalam penelitian ini adalah siswa kelas IV SD 2 Bae yang berjumlah 15 siswa. Variabel bebas penelitian ini adalah penerapan model pembelajarn Numbered Head Together berbantu gamabr ilustrasi sedangkan variabel terikatnya hasil belajar siswa kelas IV. Pelaksanaan penelitian tindakan kelas ini dengan menerapakan model NHT berbantu gambar ilustrasi pada mata pelajaran PKn materi menunjukkan sikap terhadap pengaruh globalisasi siswa kelas IV SD 2 Bae.

Teknik pengumpulan data dalam penelitian ini adalah observasi, wawancara, dokumentasi dan tes. Teknik observasi dengan lembar observasi untuk mengamati hasil belajar siswa ranah afektif dan psikomotorik. Teknik wawancara menggunakan lembar wawancara untuk mengetahui data awal sebelum dilaksanakan penelitian. Teknik tes menggunakan soal evaluasi untuk mengukur kemampuan siswa dalam memahami pembelajaran yang dilakukan setiap akhir siklus. Sedangkan dokumentasi bertujuan untuk mengumpulkan data selama penelitian, dalam bentuk foto.

Analisis data yang digunakan adalah analisis data kuantitatif dan kualitatif. Jika ketuntasan klasikal mencapai 75\% maka indikator keberhasilan telah tercapai, jika kurang dari 75\% maka indikator keberhasilan belum tercapai. Ketuntasan individu dapat dilihat dengan cara membandingkan nilai siswa dengan kriteria ketuntasan minimal yaitu 70 .

\section{HASIL DAN PEMBAHASAN}

\section{Deskripsi Kondisi Pra Siklus}

Penelitian ini dilaksanakan pada siswa kelas IV SD 2 Bae pada tanggal 5-17 Mei 2018. Peneliti menganalisis hasil observasi yang telah dilakukan, sehingga didapatkan hasil belajar (prasiklus) sebelum menerapkan model pembelajaran Numbered Head Together berbantu gambar ilustras. Rekapitulasi kondisi awal prasiklus siswa kelas IV dapat dilihat pada Tabel 1 berikut.

Tabel 1. Rekapitulasi hasil belajar prasiklus

\begin{tabular}{lc}
\multicolumn{1}{c}{ Komponen } & Jumlah \\
\hline Nilai Terendah & 45 \\
Nilai Tertinggi & 85 \\
Siswa Tuntas & 5 \\
Siswa Tidak Tuntas & 10 \\
Persentase Ketuntasan & $\mathbf{3 3 , 3 3 \%}$ \\
\hline
\end{tabular}

Berdasarkan hasil belajar siswa saat prasiklus diketahui bahwa persentase ketuntasan siswa hanya sebesar $33,33 \%$, maka perlu adanya perbaikan proses pembelajaran untuk meningkatkan kualitas pembelajaran. Peneliti melakukan perbaikan pembelajaran dengan menggunakan model pembelajran NHT berbantu gambar ilustrasi sebagai upaya meningkatkan kualitas pembelajaran PKn kelas IV SD 2 Bae.

\section{Deskripsi Siklus I}

Penelitian tindakan kelas di SD 2 Bae kelas IV pada siklus I dilaksanakan dalam 2 pertemuan yang membahas tentang pengertian dan dampak globalisasi. Kegiatan siklus I diawali dengan perencanaan yaitu mengidentifikasi masalah, merancang perangkat pembelajaran (Rencana Pelaksanaan Pembelajaran, bahan ajar, media gambar ilustrasi), dan mengembangkan instrumen penilaian. Pelaksanaan pembelajaran pada siklus 
I sesuai dengan Rencana Pelaksanaan Pembelajaran (RPP) yang telah disusun. Kegiatan pembelajaran dilakukan dalam 2 pertemuan. Pada akhir siklus siswa diberikan soal evaluasi untuk mengetahui peningkatan hasil belajarnya. Hasil belajar ranah kognitif siswa dapat dilihat pada Tabel 2 berikut.

Tabel 2. Rekapitulasi Hasil Belajar Ranah Kognitif Siklus I

\begin{tabular}{lc}
\hline \multicolumn{1}{c}{ Komponen } & Jumlah \\
\hline Nilai Terendah & 60 \\
Nilai Tertinggi & 90 \\
Siswa Tuntas & 10 \\
Siswa Tidak Tuntas & 5 \\
Persentase Ketuntasan & $\mathbf{6 6 , 6 7 \%}$ \\
\hline
\end{tabular}

Hasil belajar ranah afektif dan psikomotorik diperoleh dengen lembar observasi selama pembelajaran dalam dua pertemuan. Hasil belajar ranah afektif dan psikomotorik siklus I dapat dilihat pada Tabel 3 berikut.

Tabel 3. Rekapitulasi Hasil Belajar ranah Afektif dan Psikomotorik Siklus I

\begin{tabular}{ccccc}
\hline Komponen & \multicolumn{2}{c}{$\begin{array}{c}\text { Afektif } \\
\text { Pertemuan ke- }\end{array}$} & \multicolumn{2}{c}{$\begin{array}{c}\text { Psikomotorik } \\
\text { Pertemuan Ke- }\end{array}$} \\
\cline { 2 - 5 } & $\mathbf{1}$ & $\mathbf{2}$ & $\mathbf{1}$ & $\mathbf{2}$ \\
\hline Persentase (\%) & 71,67 & 73,67 & 72,33 & 76,33 \\
Rata-rata (\%) & \multicolumn{2}{c}{72,67} & \multicolumn{2}{c}{74,33} \\
Kriteria & Baik & \multicolumn{2}{c}{ Baik } \\
\hline
\end{tabular}

Berdasarkan hasil yang diperoleh pada siklus I diktahui bahwa terjadi peningkatan hasil belajar siswa dari prasiklus ke siklus I, namun indikator keberhasilan penelitian belum tercapai karena persentase ketuntasan siswa belum mencapai $75 \%$. Hasil refleksi diperoleh bahwa siswa masih beradaptasi dengan penggunaan model pembelajaran baru. Beberapa siswa terlihat mendominasi terutama ketika kegiatan diskusi, karean gambar ilustrasi yang digunakan hanya untuk masing-masing perwakilan kelompok. Untuk mendapatkan hasil yang lebih baik lagi dan memperbaiki kekurangan yang terjadi pada siklus I saat pembelajaran maka akan dilanjutkan ke siklus II dengan memperhatikan hasil refleksi.

\section{Deskripsi Siklus II}

Perbaikan pembelajaran siklus II dilaksanakan dengan memperhatikan hasil refleksi pada siklus I. Penggunaan gambar ilustrasi dilaksanakan pada masing-masing individu untuk kegiatan diskusi kelompok. Pada akhir siklus II siswa diberikan soal evaluasi untuk mengetahui peningkatan hasil belajarnya.
Hasil belajar ranah kognitif siswa dapat dilihat pada Tabel 4 berikut.

Tabel 4. Rekapitulasi Hasil Belajar Ranah Kognitif Siklus II

\begin{tabular}{lc}
\hline \multicolumn{1}{c}{ Komponen } & Jumlah \\
\hline Nilai Terendah & 65 \\
Nilai Tertinggi & 95 \\
Siswa Tuntas & 13 \\
Siswa Tidak Tuntas & 2 \\
Persentase Ketuntasan & $\mathbf{8 6 , 6 7 \%}$ \\
\hline
\end{tabular}

Hasil belajar ranah afektif dan psikomotorik diperoleh dengen lembar observasi selama pembelajaran dalam dua pertemuan. Hasil belajar ranah afektif dan psikomotorik siklus II dapat dilihat pada Tabel 5 berikut.

Tabel 5. Rekapitulasi Hasil Belajar ranah Afektif dan Psikomotorik Siklus I

\begin{tabular}{ccccc}
\hline Komponen & \multicolumn{2}{c}{$\begin{array}{c}\text { Afektif } \\
\text { Pertemuan ke- }\end{array}$} & \multicolumn{2}{c}{$\begin{array}{c}\text { Psikomotorik } \\
\text { Pertemuan Ke- }\end{array}$} \\
\cline { 2 - 5 } & $\mathbf{1}$ & $\mathbf{2}$ & $\mathbf{1}$ & $\mathbf{2}$ \\
\hline Persentase (\%) & 79,33 & 84,33 & 81,33 & 83,67 \\
Rata-rata (\%) & 81,83 & \multicolumn{2}{c}{82,50} \\
Kriteria & Baik & \multicolumn{2}{c}{ Baik } \\
\hline
\end{tabular}

Hasil dari siklus II menunjukkan ketuntasan belajar siswa mencapai $86,67 \%$ lebih dari indikator keberhasilan yaitu $75 \%$. Berdasarkan hal tersebut, maka proses penelitian dihentikan pada siklus II. Hasil belajar siswa dari prasiklus, siklus I, dan siklus II terlihat adanya peningkatan baik dari ranah kognitif, afektif, maupun psikomotorik.

Peningkatan hasil belajar siswa dikarenakan penarapan model NHT berbantu gambar ilustrasi. Penggunaan model NHT dapat membantu siswa untuk terlibat aktif dalam pembelajaran (Hadiyanti, 2012). Keaktifan siswa dalam pembelajaran dapat membantu dalam pencapaian hasil belajar siswa dan akan mendukung tercapainya tujuan pembelajaran. Selaras dengan pendapat Batubara \& Sinulingga (2014) bahwa penerapan model NHT dalam pembelajaran dapat meningkatkan hasil belajar siswa. Siswa lebih aktif dalam kegiatan pembelajaran seperti menyampaikan pendapat, bertanya, maupun berdiskusi di dalam kelas. Kusumawati dan Mawardi (2016) dalam penelitiannya telah membuktikan bahwa penerapan model NHT dapat memberikan peluang bagi siswa untuk saling bertukar pikiran dan menyelesaikan permasalahan ataupun kasus yang diberikan oleh guru. Melalui kegiatan diskusi kelompok ini siswa lebih aktif bekerja secara kelompok untuk menemukan jawaban yang tepat dari sebuah permasalahan. Hal ini 
yang menyebabkan hasil belajar siswa khususnya ranah afektif dan psikomotorik siswa meningkat dari siklus I ke siklus II pada kriteria baik.

Peningkatan hasil belajar yang dialami siswa tidak hanya karena penerapan model NHT saja, namun didukung oleh media gambar ilustrasi yang digunakan oleh guru. Menurut Maryani (2011) media gambar ilustrasi dapat menjembatani penyajian objek yang tidak dapat dihadirkan ke dalam kelas. Fungsi gambar ilustrasi dalam pembelajaran dapat menumbuhkan stimulus terkait unsur-unsur gambar dan prinsip-prinsipnya (Dwiantari, 2019). Hal itu dapat membantu peningkatan hasil belajar siswa ranah aktif dan psikomotorik siswa. Selain itu, gambar ilustrasi dapat menumbuhkan kepekaan persepsi visual siswa dalam respon terhadap isu isu global. Gambar ilustrasi dapat bermanfaat merangsang pemahaman siswa dalam bentuk-bentuk konkret yang diabstraksikan melalui pengetahuan dan efek psikologi siswa (Putra, 2011). Gambar ilustrasi mampu merepresentasikan tingkat pengetahuan kognitif anak dalam memahami materi penogaruh globalisasi.

\section{SIMPULAN}

Penerapan model NHT berbantu media ilustrasi dapat meningkatkan hasil belajar siswa Kelas IV SD 2 Bae. Ketuntasan belajar siswa ranah kognitif meningkat dari prasiklus sebesar $33,33 \%$ meningkat menjadi $66,67 \%$ pada siklus I, dan $86,67 \%$ pada siklus II. Peningkatan haisl belajar ranah afektif dari siklus I sebesar 72,67 pada kriteria baik meningkat menjadi 74,33 pada kriteria baik. Hasil belajar ranah psikomotorik meningkat dari siklus I sebesar 81,83 pada kriteria baik menjadi 82,52 pada siklus II kriteria baik.

\section{DAFTAR PUSTAKA}

Annisa, V., Fajrie, N., \& Ahsin, M. N. (2021). Penerapan Model Problem Based Learning Berbantuan Media Kartu Gambar Ilustrasi Untuk Meningkatkan Pemahaman Konsep Siswa Kelas IV Sekolah Dasar. WASIS: Jurnal Ilmiah Pendidikan, 2(1), 1-8.

Ardianti, S. D., Wanabuliandari, S., \& Wijayanti, E. (2021). Need Analysis of "Si Eco" Ethno-Confidence Game for Slow Learner Students. Jurnal Ilmiah Sekolah Dasar, $5(3)$.

Arsini, N. N., Parmiti, D. P., \& Sumantri, M. (2015). Pengaruh Model Pembelajaran Kooperatif Tipe Numbered Head Together
(NHT) Terhadap Hasil Belajar IPS Siswa Kelas IV Semester II SD Gugus VI Kecamatan Kintamani Tahun Pelajaran 2014/2015. MIMBAR PGSD Undiksha, $3(1)$.

Batubara, F., \& Sinulingga, K. (2014). Pengaruh Model Pembelajaran Kooperatif tipe Number Head Together terhadap hasil belajar siswa smp Pada materi getaran dan gelombang. INPAFI (Inovasi Pembelajaran Fisika), 2(2).

Dwiantari, K. S., Suandi, I. N., \& Indriani, M. S. (2019). Peningkatan Kemampuan Menulis Teks Anekdot Melalui Media Gambar Ilustrasi Pada Siswa Kelas X IPA 2 Sma Negeri 2 Mengwi. Jurnal Pendidikan Bahasa dan Sastra Indonesia Undiksha, 9(2).

Hadiyanti, R. (2012). Keefektifan Pembelajaran Kooperatif Numbered Head Together Terhadap Kemampuan Pemahaman Konsep. Unnes Journal of Mathematics Education, 1(1).

Kusumawati, H., \& Mawardi, M. (2016). Perbedaan Penerapan Model Pembelajaran Kooperatif Tipe NHT dan STAD Ditinjau dari Hasil Belajar Siswa. Scholaria: Jurnal Pendidikan dan Kebudayaan, 6(3), 251-263.

Magdalena, I., Haq, A. S., \& Ramdhan, F. (2020). Pembelajaran Pendidikan Kewarganegaraan di Sekolah Dasar Negri Bojong 3 Pinang. BINTANG, 2(3), 418-430.

Maryani, A. (2011). Peningkatan Keterampilan Menulis Deskripsi Dengan Menggunakan Media Gambar Ilustrasi pada Siswa Kelas X TKR 2 SMK Muhammadiyah 1 Sukoharjo Tahun Ajaran 2010/2011 (Doctoral dissertation, Universitas Muhammadiyah Surakarta)

Nikmah, A. (2018). Peningkatan Pembelajaran Rasul Ulul Azmi Dengan Menggunakan Teknik Jigsaw Dan Media Gambar Ilustrasi Pada Siswa Kelas V SD N Tegalombo 04 Pati. Elementary: Islamic Teacher Journal, 6(1), 22-42.

Putra, N. A. (2011). Penggunaan media gambar seri untuk meningkatkan keterampilan menulis narasi pada mata pelajaran Bahasa Indonesia siswa kelas IV SDN Moahino 
Runita Firdayanti, Nur Fajrie, dan Sumarwiyah

Penerapan Model Numbered Head Together Berbantu Gambar Ilustrasi Untuk ...

WASIS: Jurnal Ilmiah Pendidikan. Volume 2 Nomor 2 Hlm. 68-73

Kabupaten Morowali. Jurnal Kreatif Online, 2(4).

Sofyan, Y., \& Agustang, A. (2018). Penerapan Model Pembelajaran Kooperatif Tipe Nht (Numbered Heads Together) Terhadap Keaktifan Belajar Siswa Kelas XI IPS 1 Sman 8 Makassar. Jurnal Sosialisasi: Jurnal Hasil Pemikiran, Penelitian dan Pengembangan Keilmuan Sosiologi Pendidikan, 158-165.

Sugiyono. 2013. Metode Penelitian Pendidikan Pendekatan Kuantitatif, Kualitatif, dan $R \& D$. Bandung: Alfabeta.

Sumarni, S. (2016). Upaya Meningkatkan Kemampuan Berhitung Melalui Penerapan Model Pembelajaran Numbered Heads Together Dengan Pemanfaatan Alat Peraga Sederhana Materi Pembagian Siswa Kelas II. Refleksi Edukatika: Jurnal Ilmiah Kependidikan, 7(1), 58-68. 